\title{
Reflective writing on English news video: Using Edmodo in an EFL college-level writing course
}

\author{
Hsieh, Hsin-Chieh Kahlen \\ Department of English Language and Literature, Fu Jen Catholic University, Taiwan (hsinchieh73@gmail.com) \\ Shih, Yu-Chih Doris $\$ \\ Department of English Language and Literature, Fu Jen Catholic University, Taiwan (dshih@mail.fju.edu.tw) \\ Wei, Yi-Chun Sherri \\ Department of English Language and Literature, Fu Jen Catholic University, Taiwan (055082@mail.fju.edu.tw)
}

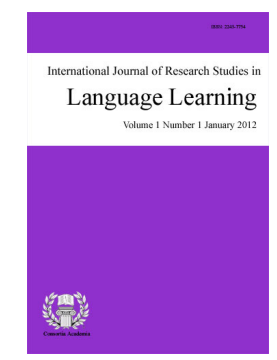

ISSN: $2243-7754$ Online ISSN: 2243-7762

OPEN ACCESS \begin{tabular}{lll} 
Received: 3 October 2018 & Revised: 14 December 2018 & Accepted: 18 January 2019 \\
Available Online: 14 February 2019 & DOI: $10.5861 /$ ijrsll.2019.3099 & \\
\hline
\end{tabular} Available Online: 14 February 2019

\section{Abstract}

In order to reinforce EFL and college students' critical thinking skill in their English writing, an after-class activity of reflective essay writing on English news videos may be a method to facilitate improved writing performance. In addition, since small group learning is an effective way to enhance students' critical thinking skill, teachers and students can use Edmodo, a private social communication platform, to connect with each other and conduct collaborative learning. The purposes of this study are first, to examine whether college-level EFL college students will show improvement in their writing (that is, the writing ability and critical thinking shown in the contents) after they watch English news videos; second, to investigate students' perceptions about reflective writing on English news videos; and third, to find out their perceptions on the use of Edmodo for peer discussions. The participants in this study were 16 EFL English-major junior students in a private university in the northern Taiwan. Both quantitative and qualitative data were collected and analyzed through descriptive statistics, non-parametric test analysis, Kaplan-Meier method, document analysis, and content analysis. The scores revealed that students made significant progress in English writing and critical thinking between the essays. The majority of the students showed positive attitude toward this activity and commented that Edmodo was easy for them to discuss and upload assignments. The study is helpful for language teachers who are interested in reinforcing critical thinking in English writing and exploring the use of Edmodo in the EFL/ESL college-level composition courses.

Keywords: English composition; critical thinking; student perceptions; Learning Management System; Taiwan 


\section{Reflective writing on English news video: Using Edmodo in an EFL college-level writing course}

\section{Introduction}

Developing critical thinking among college students is a fundamental aim of modern education. Critical thinking is viewed as an important attribute for college students when they enter into the workforce; it is identified as one of the essential skills that college students need to acquire in order to be successful in their future careers (Carmichael \& Farrell, 2012; Jance \& Morgan, 2013). Therefore, it is necessary for students to develop their critical thinking skills during their four-year bachelor's program and they are expected to be able to use critical thinking in perceiving the world (Hamdan Al Ghamdi \& Deraney, 2013). However, though higher education has put an emphasis on teaching or developing students' critical thinking skills and has kept advocating the importance of critical thinking, most college students were still unprepared to think critically or had limited development of their critical thinking skills after they start their careers (Flores, Matkin, Burbach, Quinn, \& Harding, 2012).

In addition, there are more and more students who receive their bachelor's degree but are not necessarily equipped with better critical thinking skills (Tsui, 2002). Some researchers also found that students could not think critically since the teachers did not integrate critical thinking sufficiently into the students' daily practices (Choy \& Cheah, 2009; Rudd, 2007). Ge's (2012) study showed critical thinking among more and more college students has deteriorated and it is difficult for them to convey their thoughts through English writing. Moreover, they even presented English writings without much context and simple vocabulary and grammar structure. Barnawi's (2011) study claimed that though the concept of critical thinking has been widely discussed in English as a second language (ESL) learning, little attention has been given on English as a Foreign Language (EFL) in college writing courses. Consequently, one aim of the current study is to examine whether EFL college students can improve their writing skills and critical thinking after they watch English news videos and write reflective essays.

In order to reinforce EFL college students' critical thinking skills in their English writing, an after-class activity reflective essay writing on English news videos may be a method to improve their writing performance. Reflective thinking is thought to enhance critical thinking since reflective thinking is a process of analyzing and making judgments about an event, a situation, or a phenomenon (Dewey, 1933). News is a source of authentic input with advanced words and terms. Gilmore (2007) indicated that real messages produced by a real speaker for a real audience is authentic language. Besides, visual learning is a method that help learners associate thoughts and information with images and it can assist learners in constructing meanings and ideas (Jonassen, 1996; Thomburg, 1998). Clark and Lyons (2004) claimed that visuals can support critical psychological learning processes. These learning processes are "support attention," "activate or build prior knowledge," "minimize cognitive load," "build mental models," "support transfer of learning," and "support motivation." Therefore, news videos can be a good source of material for EFL learners to assist their critical thinking and information processing in a better way. In addition, students are recommended to write reflective essays after class instead of writing them in class since after-class writing can reduce students' writing anxiety. According to cognitive psychology and educational psychology, students' language proficiency would diminish if they were asked to accomplish tasks they were not familiar with and also if they were in a stressful condition (Ge, 2012).

\subsection{Research Purposes and Questions}

The purposes of this study are, first, to examine whether having reflective essay writing after students watch English news videos help EFL college students improve their writing skills and critical thinking in composition writing; second, to investigate students' perceptions about reflective writing on English news videos activity; and 
third, to find out students' perceptions on the use of Edmodo. Three research questions are proposed in this study.

$>\quad$ Is there a statistical significant difference in students' composition of pre-test vs. reflective essay 1 , reflective essay 1 vs. 2 , and reflective essay 2 vs. 3 ?

$>\quad$ Is there a statistical significant difference in students' improvement on critical thinking of pre-test vs. reflective essay 1 , reflective essay 1 vs. 2 , and reflective essay 2 vs. 3 ?

$>\quad$ How do students feel about reflective writing and using Edmodo in the activity of reflective writing on English news videos?

\section{Literature Review}

\subsection{News Videos in English Writing}

According to Stempleski (1987), "a rich and exciting source of video software for EFL/ESL classes is authentic material" (p. 3). She advocated that authentic videos present real language and provide an authentic look at the culture, which can stimulate students' learning motivation, enhance their comprehension, and give them an opportunity to practice in dealing with the medium. Furthermore, language is not only learned through words; instead, visuals play an important role in language development and language learning requires association with perceptual experience (Britsch, 2012). Fazilatfar, Mohebbi, and Modrek (2016) pointed out that we cannot deny language learners can make good use of video materials and learn through different techniques. Many video sites are web-based and can be accessed easily through mobile devices for viewing (De Jesus, 2017). In the study of Black (1993), she investigated whether students improved the quality of descriptive writing by using auditory stimulus and visual stimulus as prewriting techniques. The results indicated that it was effective for students to improve their composition writing by using both auditory stimuli and visual stimuli simultaneously. Instead of reading texts, Goodson (1993) found that most Taiwanese students preferred visual approaches to learning. Asian students tended not to have better academic performance if they only received auditory as a primary mode of instruction in their college courses (Ladd \& Ruby, 1999). Therefore, by watching news videos, the EFL learners can watch the scenes and headlines and stimulate their visual sensory.

\subsection{Critical Thinking}

Writing is important for one to develop and demonstrate critical thinking skills. Critical thinking has been called "the exterior sign of an interior thinking process" (Bean, 1996, p. 20). Many scholars defined what critical thinking was but it is usually referred to as reflective thinking or deep thinking (Roybal, 2012). It is the skill to question common beliefs and overturn the beliefs which are not reasonable and which lack evidence or rational foundation (Cosgrove, 2011). It evaluates the validity and reliability of the given information (Pithers \& Soden, 2000).

Bloom (1976) claimed that critical thinking is referring to high-level thinking skills of Bloom's Taxonomy and the major components of critical thinking are analysis, synthesis, and evaluation. In the revised Bloom's Taxonomy by a new group of cognitive psychologists in the 1990s, the highest two levels are changed to "Evaluating" and "Creating". In the $21^{\text {st }}$ century, the ability of evaluating and creating are essential when it comes to critical thinking. The development of critical thinking is a focus of essential questions (Brown, 2009). Essential questions are similar to Bloom's higher level questions. Open-ended questions with no specific answers can enhance students' learning.

Some studies investigated the strategies for improving critical thinking in writing. Enabulele (2011) looked at the effectiveness of using dialectical journals as a strategy to improve student's critical thinking. The results indicated that using dialectical journals is not an effective strategy to improve students' critical thinking skills in their writing works because of the short duration for students to practice in the use of dialectical journal. It would 
be better if students could have a chance to complete their essays collaboratively with other students. From the study of Lovell and Palmer (2013), in order to increase college students' critical thinking in their writing assignments, students were asked to post their writing works on Facebook. In addition, students had to discuss with their peers on Facebook to revise their works. The findings revealed that the increase in the connection between peers on Facebook could facilitate students' strengths in analyzing and reasoning in their writing assignments.

\subsection{Reflective Writing}

Writing is a traditional but obvious medium for students to present their personal or creative thoughts and to help them become critical thinkers. According to Nelson (1989), writing not only unveils what students think, it also gives them an opportunity to develop higher order thinking skills. Reflection and reflective writing are valued in educational and workplace settings since these skills can be used to develop lifelong learning strategies (Nuffer et al., 2013). Moon (1999) defined reflection as "a form of mental processing, a form of thinking that we use to fulfill a purpose or to achieve some anticipated outcome. It is applied to relatively complicated or unstructured ideas for which there is not an obvious solution..." (p. 23). Reflective writing could also be called "journal writing" or "reflective journal writing" since in these writings, students need to brainstorm their ideas in a critical way and write their emotions, feelings, or insights with evidence. Moon's (1999) reflective writing model included six stages: Purpose (Learners know the purpose of the reflective activity); Basic observation (Learners get new information or findings); Additional information (Learners get new information or findings); Revisiting (Learners write their earlier reflections); Standing back (After having an experiment or activity, the new reflection appears); and Moving on (Something has been solved or learned in the end).

Samih's study (2014) investigated students' perceptions on writing journals. The results showed that the majority of the students agreed that journal writing was a valid tool for them to develop their ability of reflection and to improve their writing styles and critical thinking. In addition, the study of Watton, Collings, and Moon (2001) provided six suggestions for students to practice reflective writing. First, "be aware of the purpose of your reflective writing and state if it is appropriate"; second, "reflective writing requires practice and constant standing back from oneself"; third, practice reflecting writing on the same event/ incident through different people's viewpoints and disciplines"; fourth, "deepen your reflection/ reflective writing with the help of others though discussing issues with individuals and groups. Getting the points of others"; fifth, "always reflect on what you have learnt from an incident, and how you would do something differently another time"; and sixth, "try to develop your reflective writing to include the ethical, moral, historical, and socio-political contexts where these are relevant" (pp. 16-17). These tips were given to students during the in-class lecture.

\subsection{Web 2.0 Platforms and Edmodo}

With the advanced technology, there are more and more Web 2.0 platforms developed and integrated widely into education. The most popular and common Web 2.0 platforms used in English writing learning are Facebook, Twitter, Weblog, Wiki, and Google Docs. Many studies found the advantages of using these five Web 2.0 platforms in English writing course. However, there were also some disadvantages found by the researchers when these platforms were integrated into the English writing courses (Campbell, 2003; Choy \& Ng, 2007; Gralla, 2010; Hart, 2013; Shih, 2011). Compared with these five Web 2.0 platforms, Edmodo was considered to be a safe and formal social networking website for students to have effective learning (Harper, 2010; Holzweiss, 2013). With this comparison, the researchers decided to use Edomodo as a platform for the activities in this project.

Edmodo (https://www.edmodo.com) is a private virtual learning environment created on $6^{\text {th }}$ March, 2008 by Nic Borg and Jeff O'Hara. Their aims of creating Edmodo is to create a safe cyber-learning space for teachers and students to communicate with each other and connect the world to carry out collaborative learning (Alshehri, 2016; Harper, 2010; Holzweiss, 2013). It also allows educators to extend their teaching beyond the classroom. 
Students can sign up on Edmodo for free and join the group (which could be a class) created by teachers. Rivero (2013) pointed out that "Edmodo was often referred to as the Facebook of education" (p. 14). Though Edmodo is similar with Facebook, which has connected more than 27 million teachers and students around the world, it has greater teacher controls than Facebook and it provides app for smartphone or iPad users. Edmodo can also be defined as a Learning Management System (LMS) and universities choose them over other types of LMS because of its flexibility to support collaborative learning and discussions (Amirul Islam, 2017; Santikarn \& Wichadee, 2018).

Since Edmodo was established in 2008, there have been studies that integrated this platform into different courses to see the effectiveness in teaching and learning. In Scott's (2012) study, he integrated Edmodo in a high school Spanish course in the US. The findings revealed that Edmodo was simple for students to use and convenient to share information. Moreover, students were satisfied with the immediate feedback and different perspectives from the discussion with other classmates. Overall, Edmodo enhanced students' interest in learning. In Richardson's study (2012), he implemented Edmodo for collaborative learning among fifth grade students in Hawaii and Maryland. The results showed that it was easy for teachers to use Edmodo to create small groups for students to have online discussions and enhanced their collaborative learning. In addition, it was a tool to have student-directed interaction among students and teachers. For English language learning at the university level, Amirul Islam (2017) explained how he chose Edmodo and designed writing materials on paragraph writing to be placed in this LMS. Students could vote on their likes or dislikes of the task. Parents could also check the details on what the learners and teacher had done. Santikarn and Wichadee (2018) adopted Edmodo in the first stage of their flipped class for English language learners to watch instructional video, do quizzes, and answer questions on language usage and vocabulary. Students were satisfied with Edmodo, "with the features of Edmodo which promoted mutual learning, they could share content, discuss topics, and ask questions very fast" (p. 132).

\section{Methodology}

\subsection{Context}

The study was implemented in a course called Junior Composition and Conversation (CCIII) in the Department of English in the Fall semester of 2013. In this course, students needed to write and analyze various types of essays (such as text analysis, problem-solving, and argumentation) and produce their own research papers. In addition, students had panel discussions with their classmates to present the processes and results of their Social Observation and Analysis Presentations (SOAP) project. Moreover, through the current study, the activity of reflective writing on English news videos was integrated into the course. There were two platforms used in this course. The first one was Engsite (the LMS used in this English Department). It was used for the instructor to upload teaching materials and also make announcements to inform students information about the course. Students also uploaded their essays, research papers, and their SOAP projects to Engsite.

The second platform was Edmodo. The instructor decided to use this LMS for the English news video activity because Edmodo allowed greater freedom for collaborative learning and student-student discussions in a closed-environment. Besides using computer to access this platform, students could also download and install the Edmodo app to their mobile devices for use. After creating a course on Edmodo, the teacher asked students to create their own free student account and joined the course using the course code. For the reflective writing on English news videos activity, all of the materials related to this activity were uploaded to Edmodo by the instructor and the teaching assistant, including journal guidelines and news video links under the assignment area. Voting by the students for their favorite topics of discussion was done through the "poll" function (created by the teacher). Also, eight small groups were created in Edmodo for all 16 students in the course. The students had to enter their own paired discussion area on the left hand side of the screen to conduct group discussions before they write their reflective writing. After sufficient discussion, students wrote their reflective writing and turned in the file to the assignment area for grading (see Figure 1 for a screen capture of Edmodo for the activity). The 
course could also add parents into it to keep them informed on what their children were learning. This course was a college-level course in which learners were adults already; therefore, the instructor did not choose to use this function.

\subsection{Participants}

The participants in this study were sixteen junior EFL English-major students (identified as A to P) in a private university in northern Taiwan. All students had to complete the English news video reflective writing activity as part of the course. Each student was invited to participate in this study and received an informed consent form near the end of the semester. All of them signed the informed consent form after understanding the purposes of the current study and were willing to allow the researchers interview them and review their documents. Twelve of the students were female and four were male. Their ages ranged from twenty to twenty-one. The average years of the participants' English learning were eleven years, and most of them learned English composition writing for more than five years.

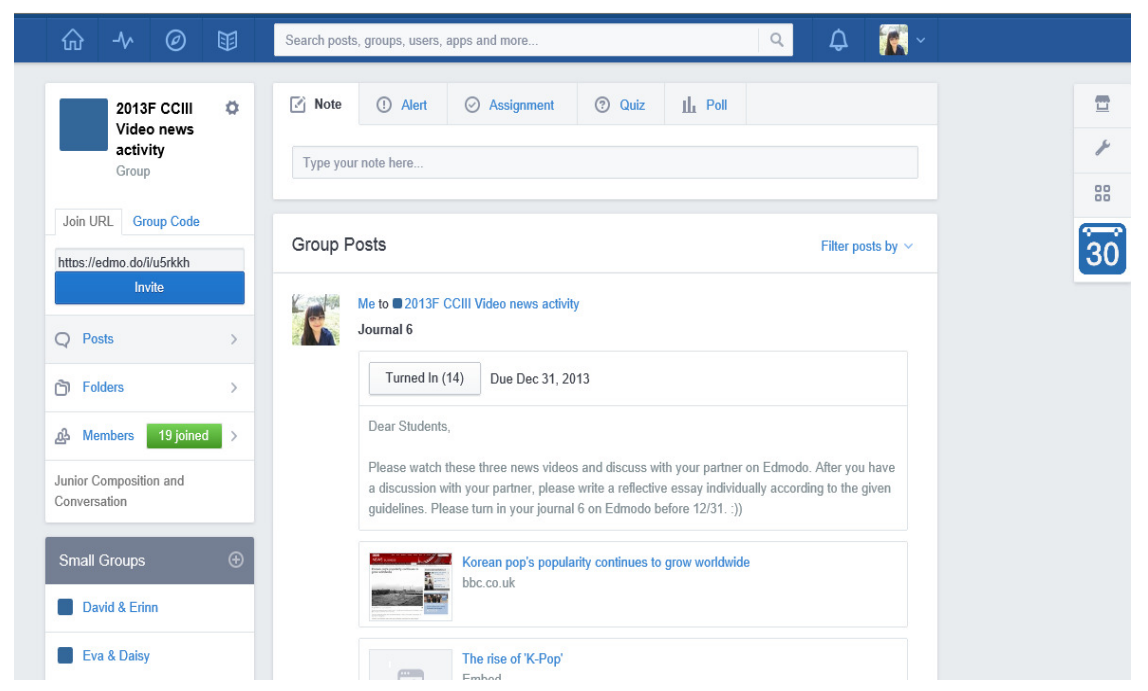

Figure 1. A screenshot of Edmodo for the activity of reflective writing.

\subsection{Materials}

Cable News Network (CNN) and British Broadcasting Corporation (BBC) News are American and British 24-hour news channels. Their official websites provide a great number of news video clips for people to watch freely. The worldwide news includes politics, business, economy, technology, arts, sports, travel, health, and entertainment. Students can write reflections on various topics and each video lasts about 3-8 minutes. It is not time-consuming for students to watch and they are not limited to one topic. For this study, 18 English news videos (three videos for each topic, six topics in total) were chosen from the CNN and BBC official websites by the researchers for students to watch. The news videos were about gun control, K-pop wave, Google glasses, smartwatch, Zuckerberg's Internet plan, and nuclear power plant. Before the activity of reflective writing on English news videos started, the 18 chosen news videos were sent to a professor of the English department for expert review in order to check whether the videos were appropriate for students to watch. All of the news videos were available online for free.

\subsection{Procedure}

The duration of the study was one semester, that is, 18 weeks. In the beginning of the course, students were each asked to do a pre-survey and a pre-test in class. In the following weeks, the researchers introduced the reflective writing on news videos activity and some strategies for watching English news videos such as 
note-taking and critical thinking. The tips on reflective writing given by Watton et al. (2001) were mentioned in class. In addition, students were taught in class how to use Edmodo and each student was asked to create an account on Edmodo for online text discussions and submission of their reflective essays. During the semester, six news topics were given to students. Students were asked to vote for their top 3 most interesting news topics on Edmodo. The first author checked the results of voting and provided the related news videos of the three top selected topics to the students to watch. Therefore, a total of nine news videos from the CNN official website and/or the BBC news official website was selected and placed on Edmodo by the instructor; this means there were three videos for each reflective essay. The guidelines were also given to the students for their reflective essay writing (See Table 1 for a sample guideline).

\section{Table 1}

Sample Videos and Guidelines for Students for Their Reflective Essays

Topic 3: Google glasses

\begin{tabular}{|l|l|}
\hline $\begin{array}{l}\text { Test-driving } \\
\text { Google Glass }\end{array}$ & $\begin{array}{l}\text { http://edition.cnn.com/video/?/video/tech/2013/05/03/pkg-lake-google-glass.cnn\&iref=videosearch } \\
\text { (accessible in 2013) }\end{array}$ \\
\hline $\begin{array}{l}\text { 2012: Future } \\
\text { vision: Augmented } \\
\text { reality }\end{array}$ & http://edition.cnn.com/video/\#/video/bestoftv/2012/04/05/exp-ns-google-glasses.cnn \\
\hline $\begin{array}{l}\text { Going gaga for } \\
\text { Google Glass }\end{array}$ & $\begin{array}{l}\text { http://edition.cnn.com/video/data/2.0/video/bestoftv/2013/05/26/rs-gaga-for-google-glass.cnn.html } \\
\text { (accessible in 2013) }\end{array}$ \\
\hline
\end{tabular}

After watching the videos, explain what is "augmented reality"? What do you think about the invention of Google glasses? Do you think the advanced technology really brings a good life or actually, there are issues we should be aware of? Please elaborate your ideas. Please type this entry in a Word file. 500-550 words, Times New Roman font, 12 font size, double-space.

In order to see the students' learning process, the students were asked to work in pairs to conduct online text discussions on Edmodo after they watched the selected news videos. After the video watching and online text discussions, they were then asked to follow the guidelines and write reflective essays individually after class and then upload the reflective essays to Edmodo. A total of three reflective essays had to be submitted by each student in the semester. At the end of the study, students were asked to fill out a post-activity questionnaire. The questionnaire was about their perceptions on this activity as well as the use of Edmodo. Additionally, six students were invited to have face-to-face interview with the first author individually.

\subsection{Data Collection and Analysis}

In order to examine whether or not EFL college students make progress on their writing skills and critical thinking in this activity of reflective writing on English news videos and also investigate students' perceptions on the activity and the use of Edmodo, seven types of data were collected: (a) Pre-survey, which included students' responses to their English learning background, technological knowledge, and composition writing knowledge; (b) Pre-test, which referred to the students' scores taken from their in-class writing at the beginning of the course; (c) Online text discussion, which was the students' peer text-based discussion on Edmodo; (d) Students' written scores and writings (identified as R1 to R3), which were taken from their reflective writing essays; there were three reflective writings; therefore, a total of 48 reflective essays were collected; (e) Questionnaire (identified as $\mathrm{PQ}$ ) with 5-point Likert scale and open-ended questions, which included students' responses to the reflective writing on English news videos activity and the use of Edmodo; (f) Interview, which included the transcripts of student's responses to their perceptions, preferences, and suggestions about this activity; and (g) researchers' online observations. 
For quantitative data, inter-rater reliability was calculated to show the reliability of three raters for the reflective essays. Kaplan-Meier curve was drawn to show the success rate (by One Minus Survival Function) of participants achieving the departmentally defined average score for English composition (78.00 out of 100.00 points) and the higher critical thinking score (3.00 out of 4.00 points). The Kaplan-Meier method is mostly used in the medical area to show patients' survival rates (such as those explained in Altman \& Bland, 1998; Bland \& Altman, 1998). The one-minus survival function was shown here for success rate. Furthermore, in order to see whether the reflective writing after watching English news videos facilitated students' composition writing performance, particularly on critical thinking in content, students' scores taken from pre-test and three reflective essays were computed and presented in statistics. The rubrics for grading the pre-test and reflective essays were based on Jacobs, Zingraf, Wormuth, Hartfield, and Hughey's scoring profile (as cited from Weigle, 2013) and Facione and Facione's (1994) Holistic Critical Thinking Scoring Rubric. There were five parts in the scoring profile, including content (30\%), organization (20\%), vocabulary (20\%), language use (25\%), and mechanics (5\%). In addition, there were four levels in Holistic Critical Thinking Scoring Rubric.

The pre-tests and reflective essays were graded by three raters and all of them agreed to follow the rubrics. One rater was the instructor (the second author of this paper), another was the teaching assistant of the course (the first author), and the third was an English composition writing teacher in the English department in another university in northern Taiwan. The three raters met in advance to have pre-training on the grading. Sample essays were read and details for grading were discussed in the pre-training. Since there were three raters for the grading, inter-rater reliability was calculated and reported. Due to the small number of participants in this study, non-parametric test analysis (Wilcoxon signed-rank test) was utilized to examine whether there was a statistical significant difference between the pre-test and each of the three reflective essays.

For qualitative data, content analysis was applied on the following: students' open-ended responses in the pre-survey, questionnaire, students' online text discussion records on Edmodo, and the transcribed interviews. They were analyzed in triangulation to answer the third research question.

\section{Results and Discussions}

\subsection{Reflective Writing}

The pre-test essay was conducted at the beginning of the semester, followed by three reflective essays during the four-month period of the semester. Since the final exam took place at the end of the semester, the third reflective essay was done by the third month. In order to ensure internal validity, the researcher calculated the inter-rater reliability according to Hatch and Lazaraton (1991). The $r$ value in the pre-test was .79; .78 in the first reflective essay; .70 in the second reflective essay; and .73 in the third reflective essay. These values indicated a high degree of correlation $(0.70 \leqq \mathrm{r} \leqq 0.99)$.

The Kaplan-Meier approach was applied and the outcome showed that 50\% (0.5) of students reached a score of 78.00 (the average score defined by the English department) by the first month. By the second month, $80 \%$ reached a score of 78.00. Finally, by the third month, only a bit over $80 \%$ reached this score (see Figure 2).

In addition, in order to see whether students' progress in the overall grade of their writing works, the average scores of the pre-test and three reflective essays by three raters were first calculated respectively. A Wilcoxon signed-ranks test indicated that there was a statistical significant difference between the pre-test $(M d n=69.40)$ and the first reflective essay $(M d n=76.85), Z=3.41, p=.001, r=.60$; also, between the first $(M d n=76.85)$ and second reflective essays $(M d n=81.25), Z=2.33, p=.02, r=.41$. However, there was no statistical significant difference between the second $(M d n=81.25)$ and the third reflective essays $(M d n=84.50), Z=0.51, p=.61, r$ $=.09$. In this case, the result revealed that there was more progress at the beginning stage of the activity. 
Figure 2. The success rate (by the score of 78.00) of the reflective writing score.

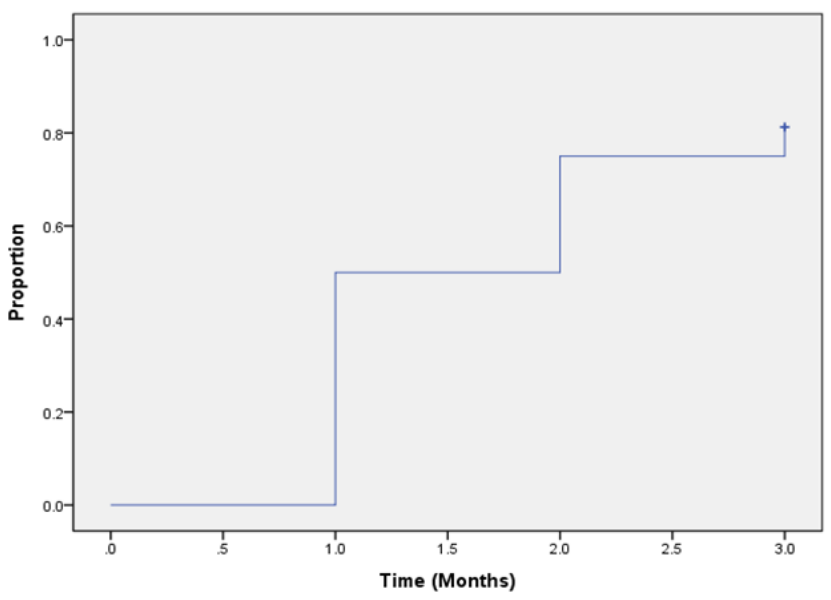

The results from each averaged overall grade showed that participants made progress on the reflective essay after they watched English news videos. Since this activity served as out-of-class activity, the scores and feedback were not given to students before the next writing (avoiding "feedback" as a confounding variable). The result is consistent with Black (1993). He indicated that it was effective for students to improve their composition writing by using both auditory stimuli and visual stimuli simultaneously. In addition, this result was also consistent with Bailey (1995), who found that the use of visuals enhanced the length and quality of compositions, students' motivation and esteem, and students' ability to organize thoughts into paragraphs.

However, after the analysis of the non-parametric test (Wilcoxon signed-rank test), though there was a statistical significant difference between the pre-test and the first reflective essay as well as between the first and second reflective essays, there was no statistical significant difference between the second and third reflective essays. From actually going through the first reflective essay, the researchers found that few students might not fully understand what reflective writing was. Therefore, they summarized the videos and gave limited reflections and analyses on the news topic. According to Xiang and Kalman (2012), reflective writing is different from summary writing. Reflective writing is to work on a self-reflection on what one has read. For the difference between summary and reflective writing is that in the former, one writes down what one already has in one's mind during the reading or listening process, while in the latter, one questions what he or she has read or listened to and relate it to other concerns. Though the instructor already gave a lecture on how to write a reflective essay at the beginning of the course, some students still did not fully understand it. Furthermore, only a bit over $80 \%$ of students reached the average point of composition score by the last reflective essay. Therefore, the instructor should provide some high-quality reflective essay samples for students to read and elaborate more to make sure they understand what reflective writing was.

In addition, some of the students reflected through the questionnaire and interviews that they did not know what Google glasses were before they watched the given news videos. The news videos gave them a chance to know more about new technologies around the world. It is consistent with Chavira (1990), who stated that "the use of authentic and fresh materials in the EFL classroom like news as instructional materials can bridge the gap between the classroom and the real world" (p. 1). Furthermore, students defined the special term "augmented reality" in their own words after they watched the given news videos and some of them even gave some examples to explain this term. Harmelink (1998) considered it is a constructive and reflective process. When students write, they will discover their ideas and provide examples for readers to have better understanding of contents.

\subsection{Critical Thinking}

Each rater was asked to give the scores according to Facione and Facione's (1994) Holistic Critical Thinking 
Hsieh, H.-C. K., Shih, Y.-C. D., \& Wei, Y.-C. S.

Scoring Rubric. Table 2 shows a sample of the analysis of critical thinking based on the rubric. The Kaplan-Meier indicates that $60 \%$ of people achieved the critical thinking score of 3.00 by the first month. At the second month, over $80 \%$ reached the score 3.00. By the third month, 100\% reached the score (see Figure 3).

Table 2

A Sample of an Analysis of Critical Thinking

Accurately interprets evidence, statements, graphics, questions, etc.

1. From one of the video clips, it is said that in some places, ordinary people need not register their guns. (R2-K)

Identifies the salient arguments (reasons and claims), pro and con.

1. In Taiwan, ordinary people are forbidden to own guns, I feel quite hard to know how it feels to have guns at home. I think that I would probably feel nervous about the preservation of guns. How to store them safely without being used by children or stolen by others is a serious issue. In addition, I will be scared when hearing the news that someone is shot by others. Will someone point at me with a gun, too? What if those who are mentally ill or crazy have guns? (R2-K)

Thoughtfully analyzes and evaluates major alternative points of view.

1. I think that there must be strict regulation of guns. People must register the numbers and types of guns they have, and the governments should send people to check and update it at least once a year or every two years. Also, those who have bad records cannot have guns. Criminals or who were once criminals as well as people who are mentally ill should definitely be prohibited of owning guns. In addition, people should preserve their guns well and make sure that others can steal their guns and young children cannot reach their hands to them. (R2-K)

Note. The writings are all kept in original without error corrections.

Critical thinking scores of students' pre-test and three reflective essays were computed to see if students made significant progress on their critical thinking in each of the reflective essay. A Wilcoxon signed-ranks test indicated that there was a statistical significant difference between the pre-test $(M d n=2.50)$ and the first reflective essay $(M d n=3.30), Z=2.86, p=.004, r=.51$. However, there was no statistical significant difference between the first $(M d n=3.30)$ and the second reflective essays $(M d n=3.40), Z=0.67, p=.50, r=.12$, nor between the second $(M d n=3.40)$ and the third reflective essays $(M d n=3.30), Z=0.06, p=.95, r=.01$, which means the null hypotheses is not rejected. Again, similar to the writing scores, the progress was clearer at the beginning stage.

Figure 3. The success rate (by the score of 3.00) of the critical thinking score.

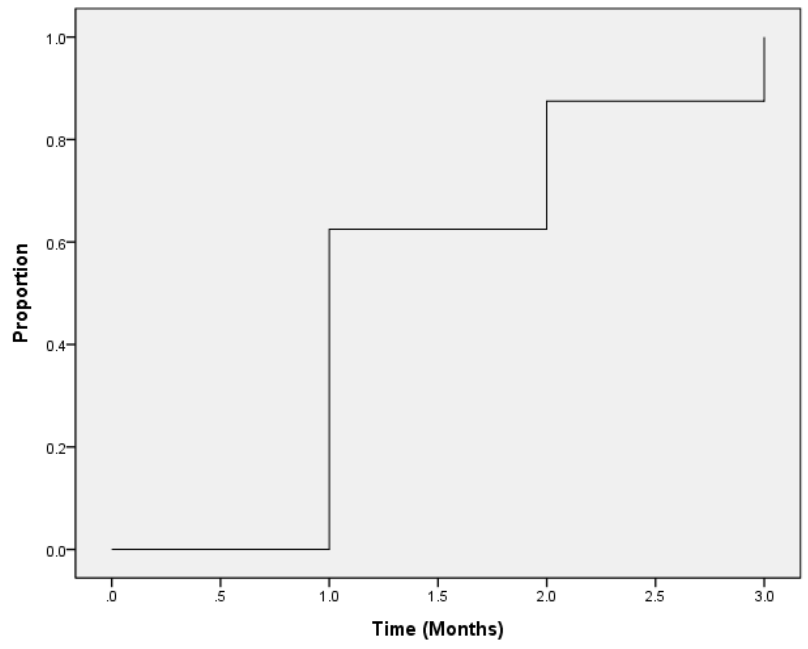

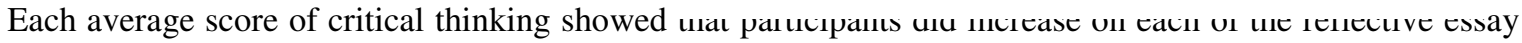
after they watched news videos. The results are consistent with the study of Hooper (1996), who claimed that images helped cultivate critical thinking when images were used in various integration in curriculum. Therefore, using English news video as an input is shown to be an effective way to enhance students' critical thinking. 
Meanwhile, reflective writing can help generate knowledge from practice and facilitate the integration of theory and practice (Hiebert, Gallimore, \& Stigler, 2002). To sum up, watching English news videos and write reflective essays are revealed to be an effective way to improve students' writing skills and critical thinking.

However, after the analysis of the non-parametric test (Wilcoxon signed-rank test) for the critical thinking score of the pre-test and three reflective essays, there is no statistical difference in students' improvement on critical thinking score between the first reflective essay and the second reflective essay on English news videos activity, nor on the second versus the third essay. The qualitative analysis showed that the choice of the essay topic is important. The participants were all third-year English-major student; therefore, most of them reflected that they would like to discuss some controversial issues in their reflective essays. It would arouse more ideas if a controversial issue is provided since they could investigate and write the advantages or disadvantages of the events or issues. Students thought the topic for the third reflective essay (K-pop) was just a common phenomenon nowadays. They did not know what to debate on or analyze. In this case, some of them wrote the reasons why they liked or disliked K-pop instead of investigating the reasons of its success or the influence of this phenomenon. It also seems that some of the students misunderstood the guidelines or did not know what to analyze about this issue. In addition, the researchers went to Edmodo and found that few students had discussions on their third reflective essay. One explanation was that some students did not have enough discussions with their classmates since the periods of discussions were near the final exam; therefore, they did not fully understand what should be analyzed and developed in their essays. The result is quite consistent with Roybal's (2012) study, which showed that many students lack of deeper understanding of materials actually affected the quality of their essays. Therefore, the preference of the topics and guidelines for students of different levels should be examined more before the activity started. Meanwhile, the role of the teacher should be an inspirer in the discussion to arouse students to ask good questions since asking questions based on thoughts and reasoning can form the baseline of critical thinking.

\subsection{The Perceptions and the Use of Edmodo for the Reflective Writing Activity}

The post survey showed that the students were positive about watching English news videos because this activity could enhance their background knowledge in current events $(M=4.56 ; S D=.51)$ and enhance their critical thinking $(M=4.50 ; S D=.51)$. It also allowed them to increase English vocabularies in writing compositions $(M=4.00 ; S D=.73)$. Furthermore, they found it helpful to have online discussions with their partners before they wrote the reflective essays $(M=3.50 ; S D=.89)$.

Students used the platform, Edmodo, to conduct peer-discussions and manage their reflective essays. At the end of the semester, participants were also asked to respond to questions about their preferences and perceptions on the use of Edmodo. For the questions about students' preferences, $87 \%$ of the students used computers to upload their reflective essays on Edmodo and 13\% of them noted that they used both computers and smartphones to upload their reflective essays on Edmodo. They strongly agreed that it was easy for them to learn how to use Edmodo $(M=4.38 ; S D=.62)$, that Edmodo was easy and convenient for them to upload the assignments $(M=$ 3.93; $S D=.95)$, and that $E d m o d o$ was also easy for them to reply to questions ( $M=3.88 ; S D=.81)$. Although they did use Edmodo to carry out peer discussions, they had a lower mean score for the item "Edmodo is convenient for me to have online text discussion with my classmates" $(M=3.44 ; S D=1.09)$.

From the qualitative data, the participants thought Edmodo was a good platform for them to have online discussions. The majority of the students liked to have discussions with their partners in this activity. They reflected that it was great to share different perspectives with each other and brainstorm for new ideas. For example, one person wrote, "[Edmodo] making it easier to have online discussion with teachers and classmates" (PQ-O). The other praises were "1. No advertisements. 2. Clear board without photos" (PQ-M); "The format is neat and simple" (PQ-N); and "Its design is simple but the function is really sufficient" (PQ-P). Four participants reflected that the notification and calendar from Edmodo could remind them to do the assignments. One person wrote, "Sweet notification!" (PQ-E). However, since two platforms (EngSite and Edmodo) were used for this 
Composition and Conversation course, the majority suggested to combine all activities into one platform only. Furthermore, it would be better to have more people in a group to conduct the discussions (four to five people would be better) to generate more ideas because in a group of two people, if one member lacks the willingness to take part in the discussion, the other member would not be able to continue the discussion.

From the responses of the post-activity questionnaire and interviews, the majority of the students reflected that Edmodo is easy and convenient for them to use. This is consistent with Scott's study (2012), which revealed one of the findings that Edmodo was easy for students to use and convenient for them to share information. In addition, "calendar" is the most liked function in Edmodo. The majority of the students agreed that the calendar on Edmodo was helpful to remind them the deadline of the news video assignments. Holzweiss (2013) actually pointed out that it is better for students to see their assignments or projects deadlines and some important reminders on the calendar. It was also convenient for students to see the entire announcements if they click on the reminders. Meanwhile, students were also satisfied with the function for them to turn in their essays on Edmodo since most of the Web 2.0 platforms did not have this function specifically for instructors and students.

\section{Conclusion}

\subsection{Pedagogical Implications}

The study was designed to investigate whether the authentic material, English news videos, could help college-level EFL students enhance their composition writing and critical thinking by writing reflective essays after they view the video clips. The study built on applying Edmodo as a medium for students to interact with each other online and experience a different Web 2.0 platform.

There are several implications for language instructors who would like to use reflective writing on English news videos activity to enhance students' writing performance and critical thinking. First, the instructor can give more news topics on different fields for students to choose. The current study only provided six news topics for students to vote on and the topics were categorized as technology and social issues. It would increase students' interest if the instructor gives different news topic in various fields, for example, business, travel, entertainment, world sport, or technology.

Second, though the instructor taught all of the participants to use Edmodo at the beginning of the course, not all the students were clear enough on using it. The recommendation for the instructors is that they should use only one learning platform in a course to increase the time the participants use the platform, letting students get more familiar with the platform and reduce their anxiety on using it.

Third, due to different personalities and learning styles of the students, the researchers should investigate students' preference on group discussion before the course started. Some of the students may want to discuss with more people in order to generate more ideas while others are happy with paired groups because two people in a group are more private for them to share their own perspectives.

Finally, teacher or teaching assistant can give some feedback on students' discussion on Edmodo in order to increase their motivation and encourage them to generate more ideas. However, in order to avoid the "instructor's feedback" factor as a confounding variable, there is no need for the instructor to join the group discussion and discuss with the students since this might interfere with the reliability of students' essay writing.

A recommended model for reflective writing on news videos activity in an EFL college writing classroom is presented in Figure 4. In this model, there are seven stages, including "platform," "lecture," "poll," "input," "guidelines for reflective essay," "online discussion," and "transfer." Compared with Moon's (1999) reflective writing model, the model for reflective writing on news videos activity provides a framework for students to know the purpose of the reflective activity and get new information or findings by receiving input and having additional activity (online discussion). However, the last stage in the model for reflective writing on news videos 
activity is different from Moon's. In Moon's reflective writing model, the last stage is "Moving on," which means something has been solved or learned in the end. Similarly, in the last stage of the model for reflective writing on news videos activity, students would combine or extend their knowledge into the writing of other papers for advanced purpose.

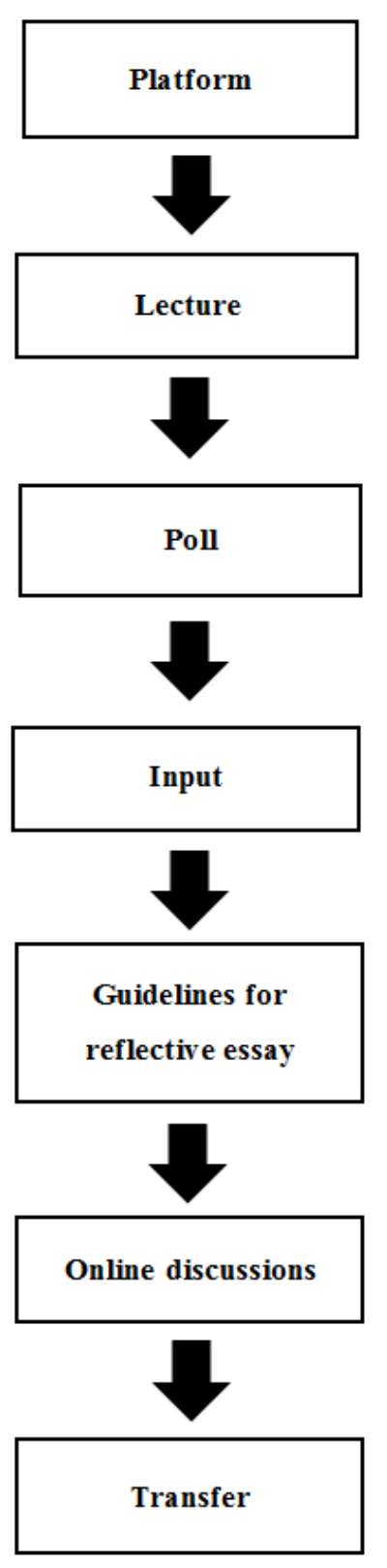

Instructor finds a platform which has a clear category in a web page (e.g., teaching materials area, small group discussion area, assignments turn in area) and with immediate notifications.

Instructor gives a lecture on what critical thinking is and how to write a reflective essay. Make sure every student is familiar with the platform and the activity.

Students find news topics they are interested in and do a poll to select some news topics for reflective essays.

Instructor gives students two or three news videos and a piece of text-based news in order to provide them with the background knowledge of the news events.

Instructor gives guidelines to students to write the reflective essays.

Instructor provides questions for students to brainstorm and form four to five students in a group to conduct online discussions.

Students combine or extend news issues into other papers or presentations (e.g., argumentation paper, research paper, or social analysis and observation presentation).

Figure 4. A recommended model for reflective writing on news videos activity in an EFL college writing classroom.

\subsection{Limitations of the Study and Suggestions for Future Studies}

Though this study gave some helpful findings to educators who teach English writing in EFL classrooms, it also has some limitations which could be improved. First, the current study only involved 16 English major students in northern Taiwan. These 16 EFL participants cannot represent the whole group of EFL learners. It would be better to have more participants in this study in order to gain a higher degree of reliability. Second, in the face-to-face interviews, the first author asked six participants' preference on watching English news videos or reading English text-based news to practice writing. In order to compare different results between watching 
English news videos and reading English text-based news, it would be better if the researchers can group the participants into control and experimental groups. Third, there might be other confounding variables that researchers did not have a chance to look into such as familiarity with the assignment and the training of "expressiveness" from other courses.

In addition, based on the results of the study, there are some suggestions for future studies. First, investigate whether there are more international news videos like CNN and BBC that can be effective materials for students to enhance their critical thinking in English writing. Second, more and more educators investigate the effectiveness of integrating different Web 2.0 platforms in English writing courses. Besides Facebook, wiki, and blogs, as well as Edmodo, researchers in the future study could also look into other newer or additional Web 2.0 platforms that could assist students' foreign language learning effectively.

Acknowledgement - An earlier version of this paper was presented by the first author at the $5^{\text {th }}$ Renmin University-Fu Jen Catholic University Graduate Student Conference held in Beijing, China, in 2014. The authors would like to thank the participants in this study. Furthermore, we would like to express our gratitude to the editors and anonymous reviewers for their constructive comments and suggestions.

\section{References}

Alshehri, B. (2016). The positive impacts of Social Network Sites (SNSs) on students' learning (comparing between Facebook and Edmodo). In G. Chamblee \& L. Langub (Eds.), Proceedings of Society for Information Technology \& Teacher Education International Conference 2016 (pp. 1775-1781). Chesapeake, VA: Association for the Advancement of Computing in Education (AACE).

Altman, D. G., \& Bland, J. M. (1998). Time to even (survival) data. BMJ, 317, 468-9. https://doi.org/10.1136/bmj.317.7156.468

Amirul Islam, C. K. M. (2017). Learning Management System (LMS) to introduce collaborative language learning at tertiary level in Bangladesh. ASA University Review, 11(2), 77-83.

Bailey, M. (1995). The impact of integrating visuals in an elementary creative writing process. Paper presented at the Annual Conference of the International Visual Literacy Association, Chicago, IL.

Barnawi, O. Z. (2011). Finding a place for critical thinking and self-voice in college English as a foreign language writing classrooms. English Language Teaching, 4(2), 190-197. https://doi.org/10.5539/elt.v4n2p190

Bean, J. C. (1996). Engaging ideas: The professor's guide to integrating writing, critical thinking and active learning in the classroom. San Francisco, CA: Jossey-Bass.

Black, J. (1993). The effects of auditory and visual stimuli on tenth graders' descriptive writing. Retrieved from http://eric.ed.gov/?id=ED364887

Bland, J. M., \& Altman, D. G. (1998). Survival probabilities (the Kaplan-Meier method). BMJ, 317, 1572. https://doi.org/10.1136/bmj.317.7172.1572

Bloom, B.S. (1976). Human characteristics and school learning. New York, NY: McGraw-Hill.

Britsch, S. (2012). Image as language: Teacher-created photographs and visual literacy for English language learning. Australasian Journal of Early Childhood, 37(2), 113-121.

Brown, K. (2009). Questions for the 21st - century learner. Knowledge Quest, 38(1), 24-29.

Campbell, A. (2003). Weblogs for use with ESL classes. The Internet TESL Journal, 9(2). Retrieved from http://iteslj.org/Techniques/Campbell-Weblogs.html

Carmichael, E., \& Farrell, H. (2012). Evaluation of the effectiveness of online resources in developing student critical thinking: Review of literature and case study of a critical thinking online site. Journal of University Teaching and Learning Practice, 9(1), 1-19.

Chavira, R. (1990). Use of the newspaper in ESOL. The Review, 2(4), 1-3.

Choy, S. C., \& Cheah, P. K. (2009). Teacher perceptions of critical thinking among students and its influence on 
Reflective writing on English news video: Using Edmodo in an EFL college-level writing course

higher education. International Journal of Teaching and Learning in Higher Education, 20(2), 198-206.

Choy, S. O., \& Ng, K. C. (2007). Implementing wiki software for supplementing online learning. Australasian Journal of Educational Technology, 23(2), 209-226. https://doi.org/10.14742/ajet.1265

Clark, R. C., \& Lyons, C. (2004). Graphics for learning: Proven guidelines for planning, designing, and evaluating visuals in training materials. San Francisco, CA: Pfeiffer.

Cosgrove, R. (2011). Critical thinking in the Oxford tutorial: A call for an explicit and systematic approach. Higher Education Research \& Development, 30(3), 343-356. https://doi.org/10.1080/07294360.2010.487259

De Jesus, R. (2017). Using videos and video-conferencing to traverse transactional distance. International Journal of Research Studies in Educational Technology, 6(2), 47-63. https://doi.org/10.5861/ijrset.2017.1851

Dewey, J. (1933). How we think: A restatement of the relation of reflective thinking to the educative process. Boston, MA: Houghton Mifflin.

Enabulele, A. (2011). Critical thinking in secondary language arts: Teacher perceptions and relevant strategies (Unpublished master's thesis). Indiana University, South Bend, IN.

Facione, P. A., \& Facione, N. C. (1994). Holistic critical thinking scoring rubric (HCTSR). Retrieved from https://www.insightassessment.com/Resources/Teaching-Training-and-Learning-Tools/Holistic-CriticalThinking-Scoring-Rubric-HCTSR

Fazilatfar, A. M., Mohebbi, L., \& Modrek, M. (2016). The effect of video materials on EFL learners' oral production: A task-based approach. International Journal of Research Studies in Educational Technology, 5(2), 3-12. https://doi.org/10.3991/ijet.v13i09.7792

Flores, K. L., Matkin, G. S., Burbach, M. E., Quinn, C. E., \& Harding, H. (2012). Deficient critical thinking skills among college graduates: Implications for leadership. Educational Philosophy and Theory, 44(2), 212-230.

Ge, Q. (2012). Critical thinking cultivation in college English after-class writing teaching. Journal of Teachers College Qingdao University, 29(4), 28-32.

Gilmore, A. (2007). Authentic materials and authenticity in foreign language learning. Language Teaching, 40(2), 97-118. https://doi.org/10.1017/S0261444807004144

Goodson, T. J. (1993). Learning style preferences of East Asian ESL students (Doctoral dissertation). University of Tennessee, Knoxville, TN. https://trace.tennessee.edu/utk_graddiss/1254/

Gralla, P. (2010). Google docs better; ready to take on office. Computerworld. Retrieved from http://www.cio.com.au/article/344145/google_docs_better_ready_take_office/

Hamdan Al Ghamdi, A. K., \& Deraney, P. M. (2013). Effects of teaching critical thinking to Saudi female university students using a stand-alone course. International Education Studies, 6(7), 176-188. https://doi.org/10.5539/ies.v6n7p176

Harmelink, K. (1998). Learning the write way. The Science Teacher, 65(1), 36-38.

Harper, A. L. (2010). Social networking with Edmodo: Let your digital footprints lead the way. Kentucky English Bulletin, 59(2), 19-21.

Hart, J. (2013). Centre for learning and performance technologies. Retrieved from http://c4lpt.co.uk

Hatch, E., \& Lazaraton, A. (1991). The research manual: Design and statistics for applied linguistics. Rowley, MA: Newbury House.

Hiebert, J., Gallimore, R., \& Stigler, J. W. (2002). A knowledge base for the teaching profession: What would it look like and how can we get one? Educational Researcher, 31(5), 3-15. https://doi.org/10.3102/0013189X031005003

Holzweiss, K. (2013). Edmodo: A great tool for school librarians. School Library Monthly, 29(5), 14-16.

Hooper, W. L. (1996). Teaching critical thinking in the fine arts. The Journal of General Education. 45(1), 1-17.

Jance, M., \& Morgan, A. (2013). Critical learning skills for business students. American Journal of Business Education, 6(1), 25-31. https://doi.org/10.19030/ajbe.v6i1.7480

Jonassen, D. H. (1996). Computers in the classroom: Mindtools for critical thinking. Englewood Cliffs, NJ: Prentice-Hall. 
Hsieh, H.-C. K., Shih, Y.-C. D., \& Wei, Y.-C. S.

Ladd, P. D., \& Ruby, R. (1999). Learning style and adjustment issues of international students. Journal of Education for Business, 74(6), 363-367. https://doi.org/10.1080/08832329909601712

Lovell, E., \& Palmer, P. (2013). Engaging introductory writing students through Facebook assignments. About Campus, 18(1), 25-28. https://doi.org/10.1002/abc.21109

Moon, J. A. (1999). Reflection in learning and professional development: Theory and practice. London, UK: Kogan Page.

Nelson, L. (1989). Critical thinking about critical thinking. Teaching Forum, 10, 1-2.

Nuffer, W., Vaughn, J., Kerr, K., Zielenski, C., Toppel, B., Johnson, L., \& McCauley, P. (2013). A three-year reflective writing program as part of introductory pharmacy practice experiences. American Journal of Pharmaceutical Education, 77(5), 1-8. https://doi.org/10.5688/ajpe775100

Pithers, R. T., \& Soden, R. (2000). Critical thinking in education: A review. Educational Research, 42(3), 237-249. https://doi.org/10.1080/001318800440579

Richardson, C. (2012). Global collaboration for elementary students. Learning \& Leading with Technology, 40(1), 30-32.

Rivero, V. (2013). What's new in the social media sphere? Internet@Schools, 20(5), 14-17.

Roybal, R. A. (2012). Creating critical thinking writers in middle school: A look at the Jane Schaffer model. Retrieved from http://eric.ed.gov/?id=ED530897

Rudd, R. D. (2007). Defining critical thinking. Techniques, 82(7), 46-49.

Samih, M. A. (2014). Reflective journal writing as a tool to teach aspects of social studies. European Journal of Education, 49(3), 395-408. https://doi.org/10.1111/ejed.12084

Santikarn, B. \& Wichadee, S. (2018). Flipping the classroom for English language learners: A study of learning performance and perceptions. International Journal of Emerging Technologies in Learning, 13(9), 123-135. https://doi.org/10.3991/ijet.v13i09.7792

Scott, S. M. (2012). Go ahead ... be social. Distance Learning, 9(2), 54-59.

Shih, R. C. (2011). Can web 2.0 technology assist college students in learning English writing? Integrating Facebook and peer assessment with blended learning. Australasian Journal of Educational Technology, 27(5), 829-845.

Stempleski, S. (1987). Short takes: Using authentic video in the English class. Retrieved from http://eric.ed.gov/?id=ED294453

Thomburg, D. D. (1998). Brainstorms and lightning bolls: Thinking skills for the $21^{\text {st }}$ century. San Carlos, CA: Starsong.

Tsui, L. (2002) Fostering critical thinking through effective pedagogy: Evidence from four institutional case studies, The Journal of Higher Education, 73(6), 740-763. https://doi.org/10.1080/00221546.2002.11777179

Watton, P., Collings, J., \& Moon, J. (2001). Reflective writing. Sheffield, UK: The University of Sheffield. Weigle, S. C. (2013). Assessing writing. Cambridge, UK: Cambridge University Press.

Xiang, H., \& Kalman, C. S. (2012). A case study on reflective writing. Journal of College Science Teaching, 42(1), 92-99. 